Journal of Community Based Environmental Engineering and Management, 2021, Vol. 5, No. 1: 9-13

\title{
PUBLIC OPINION ON NOISE DISTURBANCE DUE TO THE ACTIVITIES OF HUSEIN SASTRANEGARA AIRPORT, BANDUNG, INDONESIA
}

\author{
Lili Mulyatna*, Yonik Meilawati Yustiani, Pebby Febrianto
}

Departement of Environmental Engineering, Universitas Pasundan

\begin{abstract}
Airport is a facility to accommodate arrivals and departures as well as aircraft movements that have the potential to cause noise impacts. This research was conducted to obtain opinions from the public regarding the noise that occurs around Husein Sastranegara Airport, Bandung, Indonesia. In addition, the determination of the airport noise area was also carried out using the Weighted Equivalent Continuous Perceived Noise Level (WECPNL) method. There are 12 measurement points, namely at distances of 100 m, $500 \mathrm{~m}$, and $1500 \mathrm{~m}$ in each of the North, East, South, and West directions. Opinions regarding the noise that occurred were obtained from 150 respondents from the community around the airport. The results of the study can be concluded that the highest WECPNL index value is found on the $100 \mathrm{~m}$ runway, the WECPNL index value is 76.39 , the $500 \mathrm{~m}$ distance the WECPNL index value is 62.71 , and the $1500 \mathrm{~m}$ distance the WECPNL index value is 52.74. The results of the WECPNL index at Husein Sastranegara International Airport Bandung have a level 2 noise area where school buildings and settlements should not be allowed. The results of the interviews show that as many as $54 \%$ of respondents feel disturbed by the noise caused by the activities of Husein Sastranegara Airport.
\end{abstract}

Keywords: airport activities, noise, WECPNL

\section{Introduction}

At an active airport, there is usually a tendency to increase the frequency of aircraft flights every day and an increase in the type of aircraft used. At an active airport, accompanied by an increase in the frequency of aircraft flights, it can have positive and negative impacts on society. The presence of this industry can provide income for the region and the country and absorb a lot of workforce. However, this industry also has a negative impact on the communities around the airport if it is not controlled.

Corresponding Author:

E-mail: *)lili.mulyatna@gmail.com

Received: 23 October 2020

Revised: 17 November 2020

Accepted: 7 February 2021
Noise generated by aircraft passing through Bandung's Husein Sastranegara airport can cause disturbance to residents who live around the airport (Kusmiati et.al, 2006). Noise exposure received by the community around the airport can cause non-specific effects and sleep disturbances is a major problem that can lead to decreased quality of life (Siswati et.al, 2017). Disruption to noise can cause people to become irritable, communication problems, stress, and sleeplessness.

Noise is defined as unwanted sound which is a natural and man-made activity (Wahyuni et.al, 2019), (Mulyatna et.al, 2019). Based on the Minister of Environment Decree No. 48 of 1996 noise is unwanted noise from a business or activity in a certain level and time that can cause 
disturbances to human health and environmental comfort. Meanwhile, according to the Minister of Health Regulation No. 718/ Menkes/ Per/ XI/ 1987 noise is the occurrence of unwanted noise, disturbing and or endangering health. The definition of noise according to the Decree of the Minister of Manpower No. 51 of 1999 concerning the Threshold Value of Physical Factors in the Workplace are all undesirable voices that come from production process tools and / or work tools which are at the level of hearing loss.

One of the studies that cover airport noise and the surrounding environment is research by Silalahi et al. (2016) who conducted research on the noise of Ahmad Yani Airport in Semarang City using the Weighted Equivalent Continuous Perceived Noise Level (WECPNL) method. This method measures the cumulative noise by weighting the time and frequency of flight activities. The results obtained using the WECPNL at Ahmad Yani Airport Semarang are $72.8 \mathrm{dBA}$. The results obtained indicate that around the airport has a high intensity for residential areas or areas that are inhabited for a long time.

This study aims to measure the noise that occurs and to analyze the influence of noise on the level of public disturbance to the activities of Husein Sastranegara Airport Bandung.

\section{Research Methodology}

\section{Research sites}

The measurement location is carried out in the north, east, south and west of the runway at Husein Sastranegara Airport, Bandung. The measurement recommended distances are 100 $\mathrm{m}, 500 \mathrm{~m}$, and $1500 \mathrm{~m}$ in any direction north, east, south and west. The observation distance measured from the take-off and landing area is different for each cardinal point. This difference adapts to conditions in the field due to inaccessible area boundaries, the presence of buildings and residential areas.

\section{Noise Measurement}

The equipment used for measuring noise in this study is the Sound Level Meter (SLM). The unit of noise level is expressed in decibels weight $\mathrm{A}$ or $\mathrm{dBA}$, namely the weight corresponding to the response of the normal human ear. Noise readings are carried out for a certain period of time using a stopwatch. The working mechanism of the Sound Level Meter is that if an object vibrates, it will cause a change in air pressure that can be captured by this tool which will then move the indicator meter.

Measurements are carried out for 7 consecutive days to get the operation of the aircraft for 7 (seven) days assuming that aircraft operations at Husein Sastranegara Airport are repeated every week. In this study, there are 12 observation points, there are three observation points in each direction of North, East, South and West of Husein Sastranegara Airport.

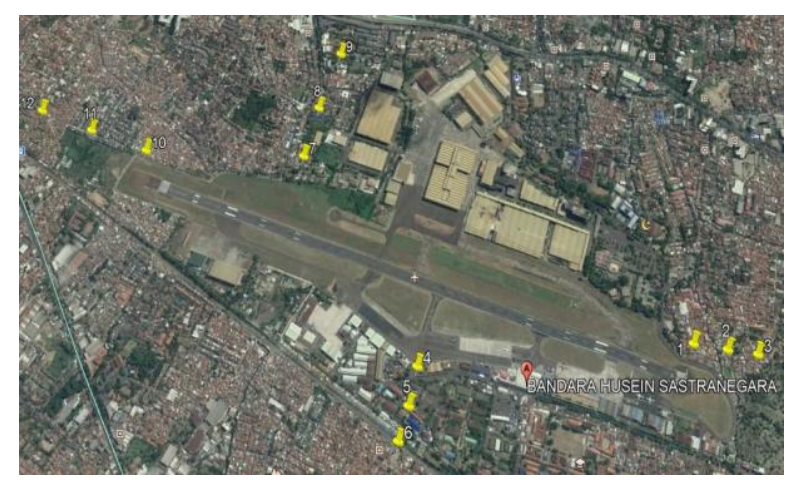

Figure 1. Sampling points.

The measurement procedure using a Sound Level Meter is as follows:

1. Before making a measurement, the Sound Level Meter is turned on early to heat the microphone so that it is free from moisture.

2. Sound Level Meter is placed at a height of 1.2 - 2 meters above the surface. 
3. Readings of numbers on the Sound Level Meter are carried out every 5 seconds for 10 minutes for each measurement time.

The total mean $\mathrm{dBA}$ value in $(\mathrm{P} / \mathrm{Po})^{2}$ is calculated by Eq. 1 .

$$
(P / P o)^{2}=10^{d B A \max / 10}
$$

Where $\mathrm{P}$ is sound pressure level $(\mathrm{Pa}), \mathrm{P} 0$ is Reference sound pressure.

$$
\mathrm{dBA}=10 \log (\mathrm{P} / \mathrm{Po})^{2}
$$

where $\mathrm{dBA}$ is the average noise level in $\mathrm{dBA}$ of the peak operation of the aircraft in 24 hours, $10 \log (\mathrm{P} / \mathrm{Po})^{2}$ is comparison between measurement sound intensity with human hearing threshold sound intensity.

The magnitude of the WECPNL noise criteria around certain airports is as follows:

$$
\begin{aligned}
& \mathrm{WECPNL}=d B(A)+10 \log N-27 \\
& - \\
& \mathrm{N}=\mathrm{N} 1+3 \mathrm{~N} 2+10 \mathrm{~N} 3
\end{aligned}
$$

where WECPNL is Weighted Equivalent Continuous Perceived Noise Level, dBA is Average noise level in dBA of the peak operation of the aircraft in 24 hours, $\mathrm{N}$ is number of arrivals and flight departure for 24 hours. $\mathrm{N}$ is number of arrivals and flight departure for 24 hours.

$\mathrm{N} 1=$ The number of aircraft operations in the period $07.00-19.00$

$\mathrm{N} 2=$ Number of aircraft operations in the period $19.00-22.00$

$\mathrm{N} 3=$ Number of aircraft operations in the period $22.00-07.00$

The measured dBA is converted to WECPNL in accordance with the number of aircraft passing for 24 hours. The WECPNL calculation is taken from the average $\mathrm{dBA}$ maximum in a day and the number of aircraft passing during certain hours is entered into $\mathrm{N}$. The formula shows that if there is an operation of one aircraft in the evening or at night it will change the correction price of $10 \log \mathrm{N}$ with evening flights $=3$ day flights and night flights $=10$ day flights .

\section{Noise Contours}

The contour map of the data from the noise measurement results is made by interpolation software. It is overlaid by earth image of the airport and vicinity in display.

\section{Community Observation}

People who are chosen to be respondents are residents who live or work in the airport area. Sampling was done using cluster random sampling. The number of respondents is 150 people.

\section{Result and Discussion}

\section{Noise Intensity}

Husein Sastranegara Airport operates every day with the operating volume of commercial aircraft that does not fluctuate, except for Indonesian Air Force aircraft which keep their operating schedules secret due to state secrets. The results of WECPNL measurements from 12 research points. Table 1 shows WECPL Measurement Results.

Table 1 WECPL Measurement Results

\begin{tabular}{ccc}
\hline No & Measuring Points & dBA \\
\hline 1 & Poin 1 & 75.51 \\
\hline 2 & Poin 2 & 62.71 \\
\hline 3 & Poin 3 & 52.11 \\
\hline 4 & Poin 4 & 62.65 \\
\hline 5 & Poin 5 & 48.03 \\
\hline 6 & Poin 6 & 41.13 \\
\hline 7 & Poin 7 & 68.74 \\
\hline 8 & Poin 8 & 53.11 \\
\hline 9 & Poin 9 & 50.11 \\
\hline 10 & Poin 10 & 67.29 \\
\hline 11 & Poin 11 & 54.33 \\
\hline 12 & Poin 12 & 42.04 \\
\hline
\end{tabular}

This WECPNL value shows that settlements at point 1 , point 4 , point 7 , and point 10 receive higher noise exposure than settlements at points $2,3,5,6,8,9,11$, and 12 . The WECPNL value 
has an effect on determining the attitudes of the people in the aircraft noise exposure area.

There is a summary of the noise exposure that occurs in residential areas under the plane's trajectory and on the right and left side of the plane's trajectory. The WECPNL distribution pattern as a noise index shows that the area under the plane's trajectory has a greater danger zone for human health above $55 \mathrm{dBA}$.

\section{Public Opinion on Noise Disturbance}

From the results of the subjective assessment, there are residential areas around the airport, which are categorized as moderate, weak to hard. This area is prone to noise hazards from the activities of Husein Sastranegara Airport. The last one is the preparation of ideal noise contours with interpolated values (Figure 2) because measurements are made in the entire area by only looking at the acoustic physical quantities measured, which can be seen on the contour map of the noise distribution.

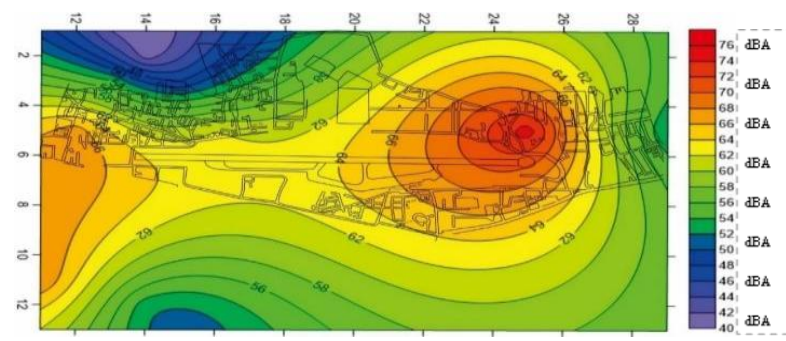

Figure 2. Noise Distribution Contour Map

From the results of interviews to 150 respondents, it was found that 68 people felt not noisy $(45.32 \%)$. Meanwhile, respondents who felt noisy were 82 people $(54.67 \%)$. Several noise control methods can be implemented to reduce airport noise levels (Liu, 2011).

\section{Conclusion}

Based on the above discussion, it can be concluded that the highest WECPNL index value is on the $100 \mathrm{~m}$ runway, the WECPNL index value is 75.51 , the $500 \mathrm{~m}$ distance the WECPNL index value is 62.71 , and the $1500 \mathrm{~m}$ distance the WECPNL index value is 52.74. In accordance with government regulation no. 20 of 2012 concerning the development of Airport Environmental preservation from the WECPNL index results at Husein Sastranegara International Airport Bandung, a solution is needed so that residential areas are not too noisy, it is necessary to install sound absorbers so that the noise from aircraft at the airport is not too noisy, and to reduce levels Noise in the area around the airport can be done by planting lush trees with spacing and height limits according to the airport environment which can function as a buffer zone. From the interview results, from 150 respondents, it was found that 68 people felt not noisy $(45.32 \%)$. Meanwhile, 82 respondents felt noisy $(54.67 \%)$.

\section{References}

Kusmiati, A., Yustiani, Y.M., Mubiarti, E. (2006), Valuasi ekonomi kebisingan pesawat udara di pemukiman sekitar Bandara Husein Sastranegara, Jurnal Teknik Lingkungan, edisi Khusus.

Liu, M. (2011). Kondisi Peredam Bising Akibat Lalu Lintas Pesawat Udara di Bandar Udara Sultan Hasanuddin Terhadap Aktivitas Masyarakat di Kawasan Permukiman Sudiang. Jurnal Transportasi. Vol. 11, No. 3 : 183-190.

Mulyatna, L., Yustiani, Y.M., Darmawan, A.R. (2019). Pemetaan Kebisingan di Ruang Departemen Spare Part dan Departemen Las Menggunakan Aplikasi Surfer. Infomatek: Jurnal Informatika, Manajemen dan Teknologi. Vol. 21, No. 2: 103-112.

Peraturan Pemerintah. 1987. Peraturan Menteri Kesehatan Republik Indonesia Nomor 718/ Menkes/ PER/ XI/ 1987 tentang Kebisingan yang Berhubungan dengan Kesehatan. Jakarta: Sekretariat Negara.

Peraturan Pemerintah. 1996. Keputusan Menteri Negara Lingkungan Hidup No. 48 Tahun 1996 tentang Baku Tingkat Kebisingan. 
Jakarta: Sekretariat Negara.

Siswati, R. Adriyani. (2017). Hubungan Pajanan

Kebisingan. Jurnal Kesehatan Lingkungan

Indonesia. 16 (1): 29-36.

Silalahi, G.S., Andarani, P., Istirokhatun, T. (2016). Analisis Sebaran Kebisingan Akibat Aktivitas Landing dan Take-off Menggunakan Software Integrated Noise Model 7.0d di Sekitar Bandar Udara Ahmad Yani Semarang. Jurnal Teknik Lingkungan, Vol. 5, No. 4: 12p.
Wahyuni, S., Yustiani, Y.M., Juliandahri, A. (2019) Analisis Tingkat Kebisingan Lalu Lintas di Jalan Cihampelas dan Jalan Sukajadi Kota Bandung. Journal of Community Based Environmental Engineering and Managemet, Vol. 2, No.1: $9-12$. 